\title{
Simulating the effect of climate on star grass growth and quality and its capacity to support milk production in the tropical regions of Mexico
}

\author{
Simulando o efeito do clima sobre o crescimento e qualidade da grama estrela e sua capacidade \\ de suporte na produção de leite em regiões tropicais do México
}

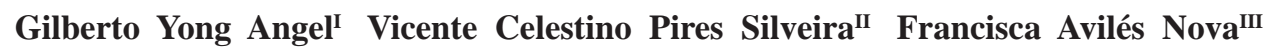 \\ Octavio Alonso Castelán Ortega ${ }^{\mathrm{IV}}$
}

\section{ABSTRACT}

The objective of the present study was to simulate the effect of the seasonal variation of climate on the nutritional value and dry matter yield of star grass and its capacity to support milk production alone or with concentrate supplementation in smallscale milk production systems in the tropical regions of Mexico. Two mathematical simulation models were used, the first model simulates the growth and yield of star grass (Cynodon plectostachyus), and the second model simulates the productive performance of dairy cows. Both models were integrated in a decision-making support system (DSSTROP). Model's predictions were validated by a calibration exercise for each data set from three experiments on the effect of concentrate supplementation on milkyield. The DSSTROP predictions and the results from the experiments were compared by regression analysis. The results suggest that the DSSTROP adequately predicts milk production $\left(R^{2}=0.74\right)$. The DSSTROP predictions suggest that milk production based solely on star grass may occur only between June to August. The highest milk yield $\left(8.5 \mathrm{~kg} \mathrm{cow}^{-1}\right.$ day $\left.^{-1}\right)$ sustained solely on grass was achieved in June, followed by lower yields of $<5 \mathrm{~kg}$ cow $^{-1}$ day $^{-1}$ in July and August. Milk production without concentrates can be explained by the positive effects of the rain observed during June to August on grass growth, and to the fact that grass quality is best at the beginning of the rainy season. It is concluded that June to August is the best time of the year for milk production base solely on grass. It also was concluded that the use of large quantities of concentrates by farmers may be justified because milk production with star grass alone may not be possible especially during the dry season.

Key words: simulation models, feeding strategies, small-scale milk production.

\section{RESUMO}

O objetivo do presente trabalho foi simular o efeito da variação sazonal do clima sobre o valor nutritivo e a produção de matéria seca do capim-estrela e a sua capacidade de apoiar a produção de leite, com ou sem suplementação concentrada, nos sistemas de produção de leite em pequena escala, nas regiões tropicais da região central do México. Foram utilizados dois modelos de simulação, o primeiro modelo simula o crescimento e produção de grama estrela (Cynodon plectostachyus), e o segundo modelo simula o desempenho produtivo de vacas leiteiras. Ambos os modelos foram integrados em um sistema de apoio à tomada de decisão para a produção de leite em regiões de clima tropical (DSSTROP). Previsões do modelo foram validadas por um exercício de calibração, para os quais foram utilizados dados de três experimentos sobre o efeito da suplementação concentrada na produção de leite. As previsões do DSSTROP e os dados obtidos foram comparados através de análise de regressão. Os resultados sugerem que o DSSTROP prevê adequadamente a produção de leite $\left(R^{2}=0,74\right)$ para as três experiências simuladas. As previsões DSSTROP sugerem que a produção de leite com base exclusivamente na grama estrela pode ocorrer apenas entre junho a agosto. A maior produção de leite $(8,5 \mathrm{~kg}$ $v_{\text {vaca }}^{-1}$ dia $\left.^{-1}\right)$, sustentada unicamente na grama foi alcançada em junho, seguido por rendimentos mais baixos de cerca de $5 \mathrm{~kg} \mathrm{vaca}^{-1} \mathrm{dia}^{-1}$, em julho e agosto. O período de produção de leite sem concentrado pode ser explicado pelos efeitos positivos da chuva, observada durante junhoagosto no crescimento do pasto, e devido ao fato de que o valor nutritivoé melhor no início da estação chuvosa. Conclui-se que entre junho-agosto é a melhor época do ano para a base de produção de leite exclusivamente com pasto. Além disso, o uso de grandes quantidades de concentrados pelos agricultores na área de estudo se justifica, pois produção de leite somente com grama estrela não é possível e talvez nem aconselhável.

Palavras-chave: modelos de simulação, estratégias de alimentação, produção de leite em pequena escala.

\section{INTRODUCTION}

Small-scale milk production represents a sustainable income option for traditional farming

IFacultad de Medicina Veterinaria y Zootecnia, Universidad Autónoma de Chiapas (UNACH), Chiapas, México.

IIDepartamento de Educação Agrícola e Extensão Rural, Universidade Federal de Santa Maria (UFSM), Santa Maria, RS, Brasil.

"IICentro Universitario Temascaltepec, Universidad Autónoma del Estado de México (UAEM), Temascaltepec, Estado de México. México.

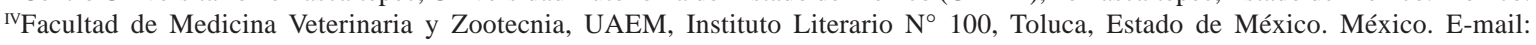

alonsooct@gmail.com. Autor para correspondência. 
families in Mexico. Its advantages have been discussed by HERNÁNDEZ-MORALES et al. (2013). However, milk production in many tropical regions of Mexico is based on the use of large amounts of commercial concentrates, up to $8 \mathrm{~kg}_{\text {cow }}{ }^{-1}$ day $^{-1}$ making dairying an expensive activity as it leaves small profits to farmers. An alternative to reduce production costs and maximize productivity of cattle is to make better use of available forage resources. However, it is well established that tropical grasses are characterized by high structural carbohydrates content, low degradation rates, low soluble carbohydrates content and less than $10 \%$ crude protein (JUAREZ et al., 1999). This is due to the climate conditions where they grow, particularly the high degree of solar radiation, meaning they lignify rapidly while their digestibility drops below 55\%. Thus, the productivity of cattle fed with tropical grasses is limited by all these factors, which result in low grass intake levels that cannot meet nutrient requirements of the animal (JUAREZ et al., 1999). On the other hand, there is limited information on the influence of the monthly fluctuations in forage composition and digestion rates on animal performance (RUEDA et al., 2003). It is therefore necessary to develop feeding strategies that take into account the effects of tropical climate on the quality of the pastures available to the animals and, at the same time make the best possible use of concentrate supplementation.

The use of concentrates is a valid resource in tropical dairying, however its use should be strategic and only when mostly needed. The development and evaluation of a large number of pasture-based feeding strategies for tropical smallscale milk production systems is limited by the funding available for research and the limited interest in this field among researchers and institutions. Thus, the use of mathematical simulation models offers the opportunity to ex ante develop and evaluate a large number of feeding strategies that make it possible to maximize the animal response, while at the same time make efficient use of locally available resources and reducing feeding costs . However, attempting to simulate both the plant and animal processes with one sole mathematical model is ambitious and not practical. The use of two or more models to simulate grass growth on the one hand and animal performance on the other is therefore presented as a more feasible option (CASTELÁN-ORTEGA et al., 2003). Thus the objective of the present paper is twofold, one is to simulate the effect of the seasonal variation of climate on the nutritional value and forage dry matter yield of star grass, and the second is to evaluate its capacity to support milk production alone or with concentrate supplementation in milk production systems in the tropical regions of central Mexico.

\section{MATERIALS AND METHOD}

The methodological approach of this research consisted on the use of two mathematical simulation models and five databases on climate, soil, nutritional characteristics of feeds, star grass growth and milk production, all integrated in a decision-making support system for milk production in tropical climate regions (DSSTROP). The first model named, Star Grass Model (SGM), simulates growth and availability of star grass (Cynodon plectostachyus). The second model is called Cow Model (CM), it was used to simulate milk production by cows grazing on star grass pastures supplemented with concentrates at different supplementation rates. The databases were obtained from three experiments carried out to determine the effect of concentrate supplementation on milk yield by dairy cows grazing on star grass swards. The experiments were carried out by LÓPEZ-GONZÁLEZ (2009) on three farms located in central Mexico at $18^{\circ} 45^{\prime} 30^{\prime \prime} \mathrm{N}$ and $99^{\circ} 59^{\prime} 07^{\prime}$ ' W, at an altitude of 1,340 meters, average temperature is $23^{\circ} \mathrm{C}$ and rainfall $1014 \mathrm{~mm}$. The results of the SGM constituted the input of the CM, which uses them in turn to simulate milk production per head and hectare. The performance of the DSSTROP was validated by a calibration exercise to assure that the system's predictions were close to the milk yield results reported by LÓPEZ-GONZÁLEZ (2009).

Star Grass Model. This model is based on the grass simulation model developed by JOHNSON and THORNLEY (1985) modified by SILVEIRA (2002) and YONG-ÁNGEL et al. (2012) in order to adapt it to simulate the growth of star grass. The SGM takes into consideration the growth of the different components of this grass. A sub-model on growth and nutrient distribution simulates the growth of the stem, leaves, and root. A photosynthesis submodel considers the plant's carbon absorption, which is determined by irradiation, temperature, and the leaf area index. The mineral nutritional sub-model represents the interface between soil and plant, where effective availability of nitrogen and phosphorous may be limited by water availability. The ontogenic sub-model represents the vegetative and senescent phase of the plant. The perturbations sub-model simulates the effect of grazing by the direct impact of the animal on the above-ground compartments of the model as described by YONG-ÁNGEL et al. (2012). 
However, grazing behavior is not simulated in this model.

Cow Model. This model is divided into two functional sections, one dynamic and one static. The dynamic section describes the digestion and flow of the feeds through the digestive tract to simulate the supply of metabolizable energy and protein from the feed to the animal. This section is based on the research of ILLIUS \& GORDON (1991). The static section estimates the animal's metabolizable energy and protein requirements based on the AFRC (1993) system, and considers the metabolizable energy and protein contribution rates from the dynamic section to simulate milk production.

Calibration of the system. The data reported by LÓPEZ-GONZÁLEZ (2009) on his three $4 \times 4$ Latin square experiments, on the effect of three levels of concentrate supplementation 5,6 , and $7 \mathrm{~kg}$ cow $^{-1}$ day $^{-1}$ of both an experimental (ExpC) and a commercial concentrate (ComC) on milk production by Holstein type cows grazing on star grass swards, was used to calibrate the DSSTROP for milk production. These authors also evaluated changes in the chemical composition of star grass over the course of one year, which included contents of crude protein, NDF, ADF, ashes, digestibility and degradation rates of carbohydrate fractions (LÓPEZ-GONZÁLEZ et al., 2010), their results were used as input to the CM model. The data on the productive characteristics of the cows used by LÓPEZ-GONZÁLEZ (2009) are shown in table 1 . The predictions of the DSSTROP for milk production were compared with the results obtained by LÓPEZ-GONZÁLEZ (2009) through lineal regression analysis for a probability level of $\mathrm{P}<0.05$.

Simulation of feeding strategies: after calibration of the DSSTROP feeding strategies were simulated for the different months of the year in order to determine when grass quality is good enough to maintain milk production with low levels of concentrate or without supplementation at all, and when it is convenient to supplement cows with concentrates. In the first case, potential milk production based solely on star grass grazing was simulated for one year. In the second case, the approach proposed by CASTELAN-ORTEGA et al. (2003) was used, which consisted in simulating a 2x3x12 factorial-type experiment, where the two concentrates: ExpC and ComC, at three supplementation rates: $1=5,2=6$, and $3=7 \mathrm{~kg}$ cow $^{-1}$ day $^{-1}$, for each of the twelve months of the year: 1: 12 were evaluated by the DSSTROP. In this way, a total of 72 feeding strategies were simulated. The chemical characteristics of the concentrates used are presented in table 1 . The ExpC was composed of $10 \%$ molasses, $3 \%$ urea, $27 \%$ soybean paste, and $60 \%$ ground corn. The ComC is the one normally purchased by dairy farmers in the region, it is composed of $35 \%$ maize or sorghum, $5 \%$ urea and a mixture of agricultural byproducts.

Table 1 - Model input data: average productive characteristics of the dairy cows for the three experimental farm used to calibrate the CM model and chemical composition of the commercial and experimental concentrates used to simulate feeding strategies.

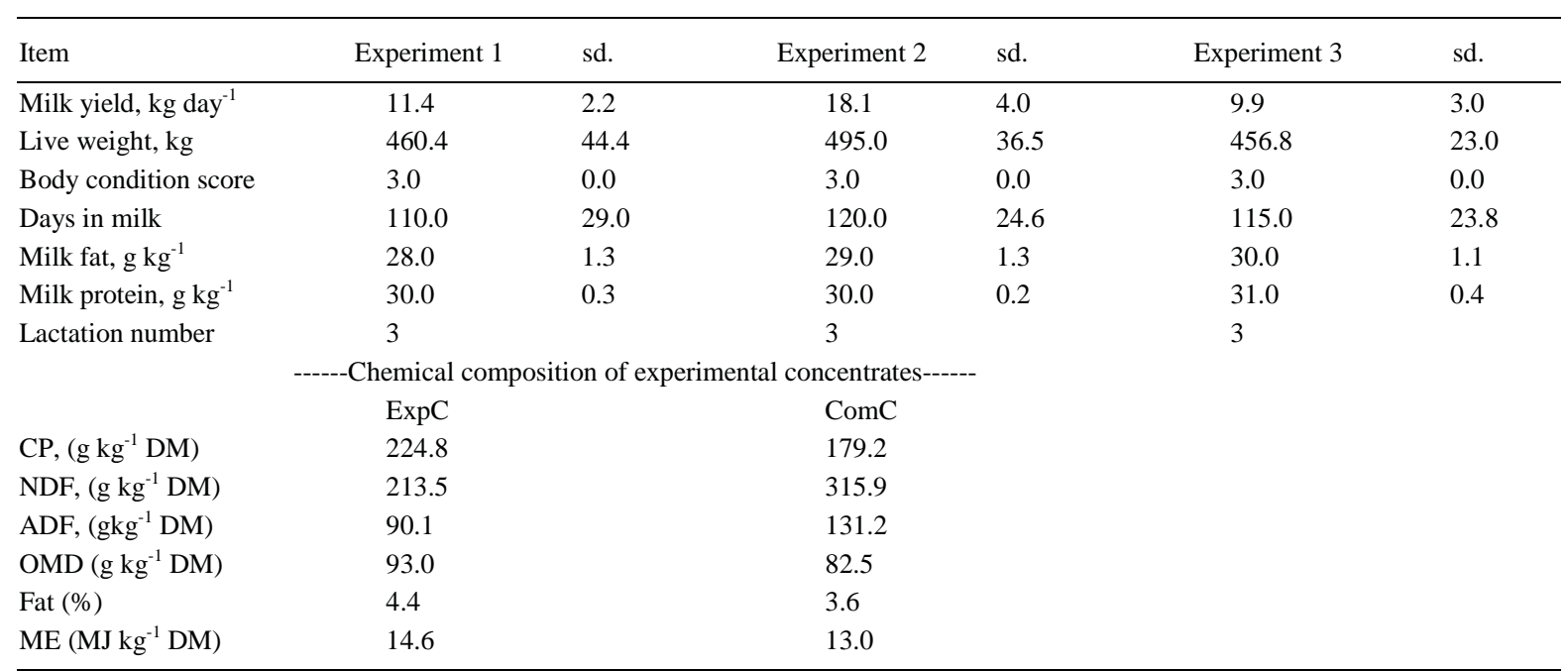

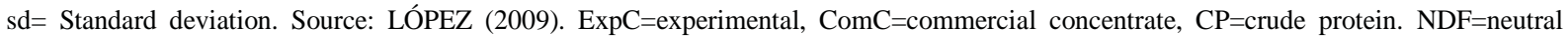
detergent fibre. $\mathrm{ADF}=$ acid detergent fibre. $\mathrm{OMD}=$ organic matter digestibility. $\mathrm{ME}=$ metabolisable energy content. 


\section{RESULTS}

Calibration of the DSSTROP. Figure 1 presents the relationship between milk production reported by LÓPEZ-GONZÁLEZ (2009) in all of his experiments and that predicted by the DSSTROP. The linear regression analysis suggests that the system adequately predicts milk production $\mathrm{R}^{2}=0.74(\mathrm{P}<0.01)$ for all the supplementation strategies evaluated.

Availability of forage. Figure 2 presents the mean average monthly herbage mass available (kg DM ha-1) simulated by the DSSTROP for an annual growing cycle, which starts in April. It can be seen that forage is available in small quantities in April (380kg DM ha-1) and it gradually increases until August when it reaches its maximum (1801kg DM $\mathrm{ha}^{-1}$ ), and then it progressively declines to return to its initial level in April of the following year. The larger availability of forage occurs during July to December when the highest rainfall occurs. Note that there is a drop in DM availability around November, this is explained by a decrease in rainfall observed around this month (Figure 2), and the SGM model was able to capture this effect. Figure 2 also shows that highest $\mathrm{CP}$ contents in star grass are predicted for June, July and August. This is explained by the onset of the rains in June, which in the Star Grass model resulted in an intense rate of production of new shoots and leaves that are rich in protein. As the plants mature the CP content declines to its lowest level $(<60 \mathrm{~g}$ of
$\mathrm{CP} \mathrm{kg}^{-1} \mathrm{DM}$ ) in February to April. This pattern is similar to that reported by LÓPEZ-GONZÁLEZ et al. (2010) for Cynodon Plectostachyus in Mexico, and by JOHNSON et al. (2001) in Florida, who mentioned that total $\mathrm{N}$ content in forage also had a quadratic relationship $(\mathrm{P}<0.01)$ with harvest month for Cynodon nlemfuensis and Cynodon dactylon.

Potential milk production based solely on star grass: figure 3a shows the DSSTROP prediction for the months in which grass quality, availability and dry matter intake make it possible to meet the metabolizable energy and protein requirements for maintenance and milk production of cows without the use of concentrates. It can be observed that the highest milk yield (8.5kg cow ${ }^{-1}$ day $^{-1}$ ) sustained solely on grass, is achieved in June followed by lower yields of nearly $5 \mathrm{~kg} \mathrm{cow}^{-1}$ day $^{-1}$ in July and August, subsequently milk yield declines to modest levels of less than $3 \mathrm{~kg} \mathrm{cow}^{-1} \mathrm{day}^{-1}$ for the rest of the year. During several months no milk is produced at all (Figure 3a). Predicted milk production without concentrates from June to August can be explained by the positive effects of the rain, observed in these months, on grass growth and to the fact that grass quality is best at the beginning of the rainy season because of the active growth of new shoots and leaves in the sward. This assumption is supported by the monthly trends of CP content and DM availability observed in figure 2. The highest CP contents were observed in these months too. These results suggest that milk

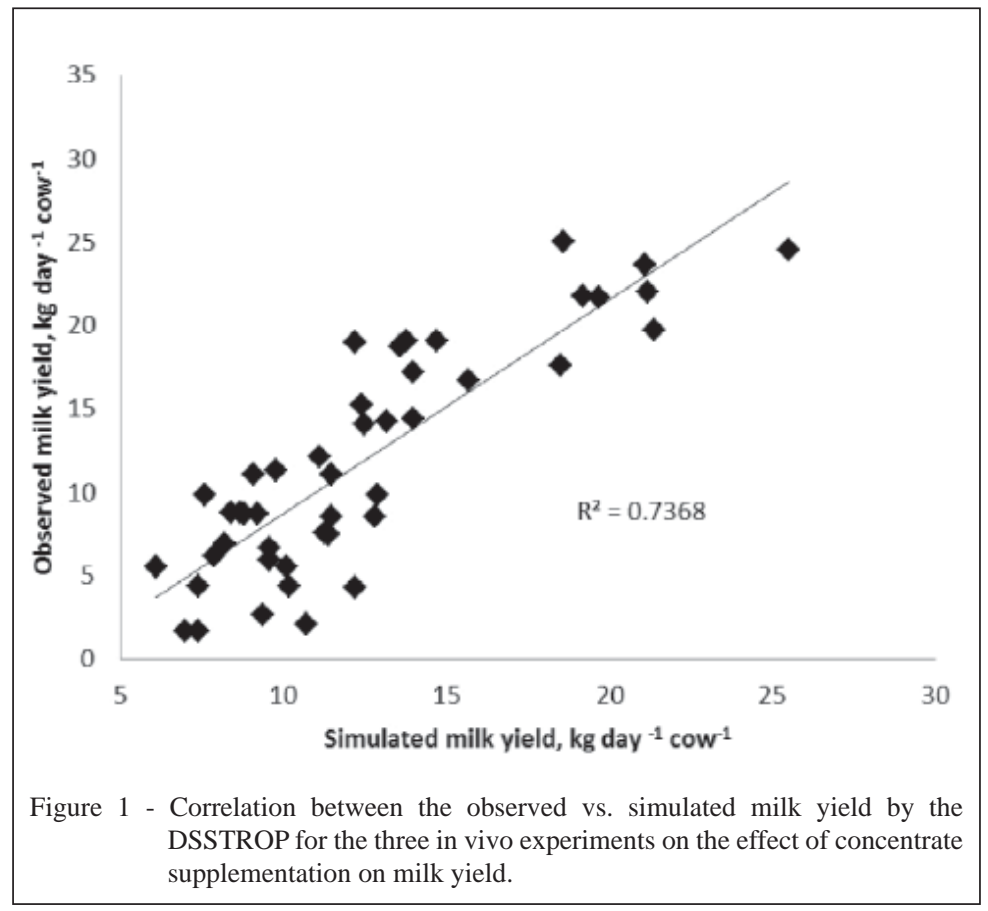

Ciência Rural, v.44, n.8, ago, 2014. 


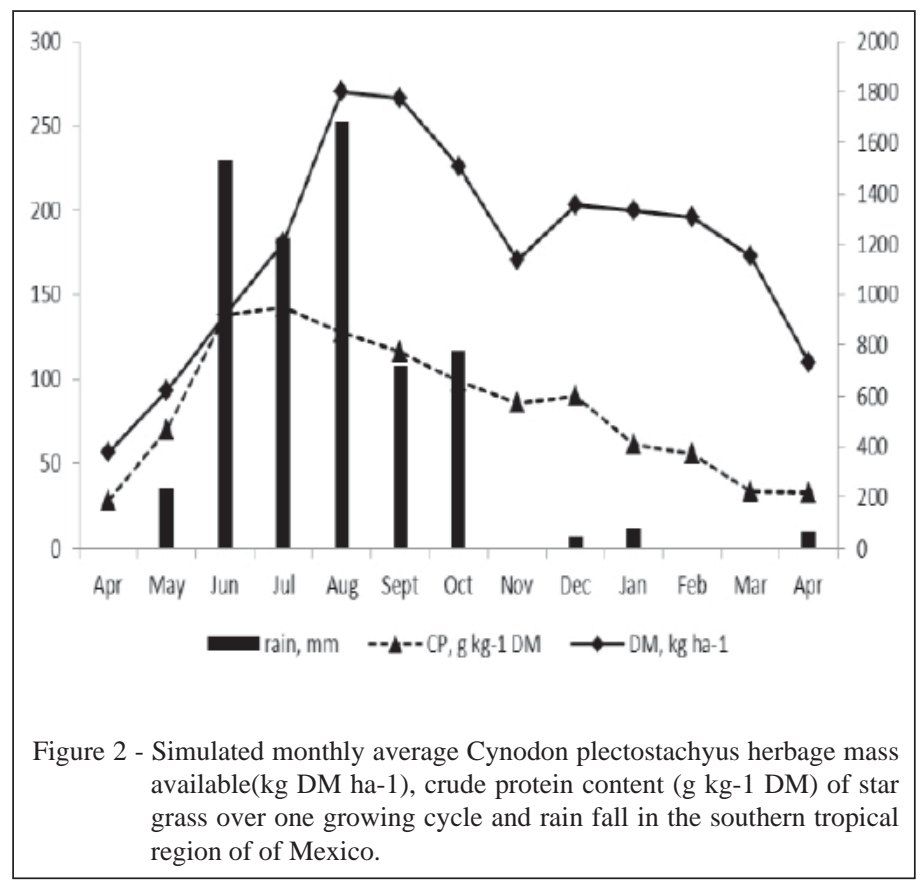

production without concentrate is only possible in a limited number of months during the year, and that the rest of the time is necessary to supplement cows with concentrates to produce milk.

Effect of supplementation level: figure 3a also presents the effect on average daily milk yield of supplementation with the experimental concentrate at rates of 5, 6 and $7 \mathrm{~kg} \mathrm{DM} \mathrm{cow}{ }^{-1}$ day $^{-1}$. These results suggest that milk can be produced throughout the course of the year with the use of concentrates, regardless of availability and quality of grass. However, it can be observed that during the dry season (December to May) supplementation with 5 and $6 \mathrm{~kg}$ head $^{-1}$ day $^{-1}$ of concentrate results in modest yields of less than $10 \mathrm{~kg}$ of milk cow ${ }^{-1}$ day $^{-1}$. This suggests that the majority of milk production at this time of the year occurs at the expense of the concentrates and that the forage intake only covers part of the maintenance requirements of cows. On the other hand, the highest yield, $22 \mathrm{~kg}_{\mathrm{g}}$ milk cow ${ }^{-1}$ day $^{-1}$ for the supplementation of $7 \mathrm{~kg}$ head ${ }^{-1}$ day $^{-1}$, occurs in June when the grass is at its optimal quality, suggesting that approximately $40 \%$ of the extra milk produced in this month comes from the grass consumed. The contribution of grass to the daily milk yield increases as the supplementation rate declines, as it passes from $45 \%$ in rate 2 to $56 \%$ in rate 1 for the same month. For the rest of the year the contribution of grass to the total milk yield is low or negligible. Figure 3b shows average predicted milk yield for the ExpC and the ComC at a supplementation rate of $5 \mathrm{~kg} \mathrm{cow}^{-1}$ day $^{-1}$, it can be seen that the ExpC is better than the ComC. This is an expected result as the quality of the ExpC is better as shown in table 1 .

\section{DISCUSSION}

The DSSTROP predictions for milk production of individual cows were significantly close to those observed by LÓPEZ-GONZÁLEZ (2009) in his experiments, and the regression coefficient $\left(\mathrm{R}^{2}=0.74\right)$ was in the confidence range reported by other authors when validate their own models (RUEDA et al., 2003). On the other hand, climate factors such as the amount of rain and ambient temperature influenced significantly the forage quality and dry matter availability simulated by the DSSTROP. These factors in turn influenced daily dry matter intake and milk yield per cow. A similar behavior was reported by SILVEIRA (2002) in a comparable simulation exercise, who indicates that climate effects and forage availability exert great influence on animal performance, because they affect forage quality throughout the year and the consumption of it by the animals. As for predicted milk yield, JUAREZ et al. (1999) found, in a similar simulation experiment, that when the cows were predicted to consume $\boldsymbol{C}$. plectostachyus $\mathrm{DM}$ at $2.1 \%$ of body weight, the amount of energy supplied from this grass was not adequate to support milk production. Also, a comparable performance is observed with dairy systems in other tropical regions of the world, for example RUEDA et al. 


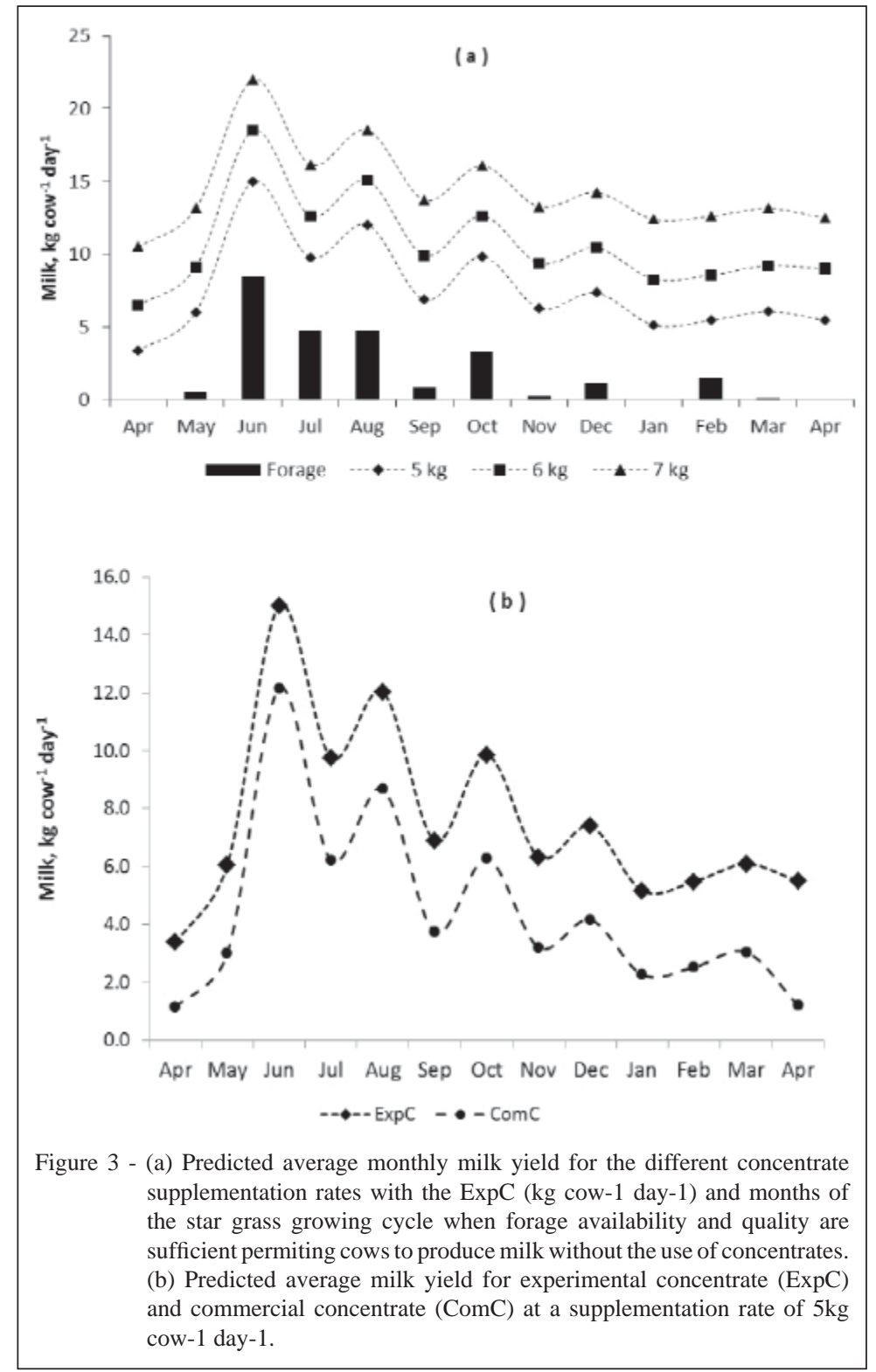

(2003) reported milk yields of $5.4 \pm 0.26$ to $8.1 \pm 0.2 \mathrm{~kg}$ cow $^{-1}$ day $^{-1}$ for cows on Brachiaria decumbens pastures without concentrate supplementation in the western Amazon region of Brazil. The predictions produced by the DSSTROP suggest that milk production derived solely from consumption of star grass (Figure 2) can occur only from June to August. This suggests that the rest of the year concentrate supplementation may be necessary to sustain milk yield. Results from LÓPEZGONZÁLEZ (2009) support this assumption; as he determined that the average amount of concentrates necessary to sustain milk production in the same study area is around $6 \mathrm{~kg} \mathrm{cow}^{-1}$ day $^{-1}$ and that it is necessary from October to May. Alike results were reported by CARVALHO et al. (2009) in Brazil, they evaluated the performance, over three years, of Holstein cows on fertilized-irrigated Cynodon dactylon grasslands and supplemented with 3 and $6 \mathrm{~kg}$ of concentrate, finding productions of 15.5 and $18.8 \mathrm{~kg}$ of milk $\mathrm{cow}^{-1}$ day $^{-1}$ respectively during the first third of lactation. The results obtained in the present research for the $6 \mathrm{~kg}$ supplementation rate were very similar to those obtained by the last authors at the same supplementation rate, $18.5 \mathrm{~kg} \mathrm{cow}^{-1}$ day $^{-1}$. Moreover, VILELA et al. (2006) also in Brazil reported a daily milk yield of $19.1 \mathrm{~kg}^{-1 a y^{-1}}$ for cows on Cynodon dactylon receiving $6 \mathrm{~kg}$ of concentrate per day. However, more validation of the DSSTROP with data from more field experiments is needed before arriving at conclusive recommendations. 
On the other hand, authors of the present paper are aware of the fact that dairy systems are complex farming systems, particularly those at the small-scale level in the tropical regions of the world, so the DSSTROP may not perform in the same manner if it is used to simulate systems that differ substantially from the one depicted here. In real life situations there are more factors, which can determine the amount of milk produced by cow grazing tropical pastures, e.g. sward characteristics, pasture mass, sward height, chemical composition etc. These factors can have a direct effect on animals' ingestive behaviour. For example, sward height is highly correlated with bite depth, bite mass and biting rate $(r=0 \cdot 91, r=079$ and $r=-0 \cdot 68$, respectively (BOVAL et al., 2007). In the same manner animals have an effect on pasture performance, for example high stocking rates would be associated with less herbage mass. These and other complex relationships between animal and pastures are not simulated by DSSTROP because they are difficult to emulate with current simulation techniques. More research is needed particularly for tropical pasture since much of continuing research on grazing behaviour has shifted to the utilization of temperate pastures. Upon comparing the experimental vs the commercial concentrate (Figure 3b), the model found higher milk production with the experimental concentrate due to its higher quality in terms of its better crude protein content, metabolizable energy content, and digestibility compared with the commercial product normally used by farmers (Table 1). Finally, results from the present research emphasize the need to introduce other grass species of better nutritional quality in order to reduce the use of concentrates and decrease production costs by supplying more nutrients from forage. As it was demonstrated, modeling can help in the ex-ante evaluation of the new grass species as there is a large variation in the milk production potential of the new grasses as demonstrated by JUÁREZ et al. (1999).

\section{CONCLUSION}

The results of the present research indicate that quality of star grass is low during most part of the year and hardly covers maintenance requirements of cows. It was demonstrated that the use of large quantities of concentrates by farmers in the study area may be justified because milk production with star grass alone may not be possible particularly during the dry season.

\section{ACKNOWLEDGEMENTS}

The funding for this project was provided by ICAMEX (grant ICAMEX 2184/2005) and Universidad Autónoma del Estado de México (grant UAEM: 2389/2006E). Their support is acknowledged.

\section{REFERENCES}

AFRC. Energy and protein requirements of ruminants. An advisory manual prepared by the AFRC Technical Committee on Responses to Nutrients. Wallingford, UK: CAB International, 1993. P.159.

BOVAL, M. et al. Effect of structure of a tropical pasture on ingestive behaviour, digestibility of diet and daily intake by grazing cattle. Grass and Forage Science, v.62, p.44-54, 2007. Available from: <http://onlinelibrary.wiley.com/doi/10.1111/ j.1365-2494.2007.00560.x/abstract>. Accessed: Mar. 13, 2014. doi: 10.1111/j.1365-2494.2007.00560.x.

CARVALHO, C.R. et al. Performance of Holstein cows in pasture of Cynodon dactylon cv16. 63 Coast-cross supplemented with concentrate. Ciência e agrotecnologia, v.33, n.6, p.1663-1670, 2009.

CASTELÁN-ORTEGA, O.A et al. A decision support system for smallholder Campesino Maize-Cattle production systems of the Toluca Valley in Central Mexico. Part 1-Integrating biological and socio-economic models into a holistic system. Agricultural Systems, v.75 n.1, p.1-21, 2003. Available from: <http://dx.doi. org/10.1016/S0308-521X(01)00109-3>. Accessed: Mar. 13, 2014.

HERNÁNDEZ-MORALES, P. et al. Tipificación de los sistemas campesinos de producción de leche del sur del estado de México. Universidad y Ciencia, v.29, n.1, p. 19-31, 2013. Available from:<http://www.redalyc.org/articulo.oa?id=15426919002> ISSN 0186-2979 Accessed: Jun. 10, 2013.

ILLIUS, A.W.; GORDON, I.J. Prediction of intake and digestion in ruminants by a model of rumen kinetics integrating animal size and plant characteristics. Journal of Agricultural Science, v.116, p.145-157, 1991. Available from: <http://journals.cambridge.org/ download.php?file=\%2FAGS\%2FAGS116_01\%2FS00218596 00076255a.pdf\&code=0d6096d56055468d454f2789ffa4ab4d $>$. Accessed: Mar. 13, 2013.

JOHNSON, I.R.; THORNLEY J.H.M. Dynamic model of the response of a vegetative grass crop to light, temperature and nitrogen. Plant, Cell and Environment, v.8, n.7, p.485499, 1985. Available from: <http://onlinelibrary.wiley.com/ doi/10.1111/j.1365-3040.1985.tb01684.x/abstract>. Accessed: Mar. 13, 2014.

JOHNSON, C.R. et al. Effects of nitrogen fertilization and harvest date on yield, digestibility, fiber, and protein fractions of tropical grasses. Journal of Animal Science, v.79, p.2439-2448. 2001. Available from: <http://www.journalofanimalscience.org/ content/79/9/2439.long>. Accessed: Mar. 13, 2014.

JUAREZ, L.F.I. et al. Evaluation of tropical grasses for milk production by dual-purpose cows in Tropical Mexico. Journal of Dairy Science, v.82, n.10, p.2136-2145, 1999. Available from: <http://www.journalofanimalscience.org/content/79/9/2439. long>. Accessed: Mar. 13, 2014 
LÓPEZ-GONZÁLEZ, F. et al. Agronomic evaluation and chemical composition of African star grass (Cynodon plectostachyus) in the southern region of the state of Mexico. Tropical and Subtropical Agroecosystems, v.12, n.1, p.151-159, 2010. Available from: <http:/ www.redalyc.org/pdf/939/93913074017.pdf>. Accessed: Mar. 13, 2014.

RUEDA, B.L. et al. Production and economic potentials of cattle in pasture-based systems of the western Amazon región of Brazil. Journal of Animal Science, v.81, p.2923-2937, 2003. Available from: <http://www.journalofanimalscience.org/ content/81/12/2923.full>. Accessed: Jun. 23, 2013.

SILVEIRA, P.V.C. Pampa corte: um modelo de simulação para o crescimento e engorda de gado de corte. Ciencia Rural, v.32, n.3, p.543-552, 2002 Available from: <http://dx.doi.org/10.1590/ S0103-84782002000300029>. Accessed: Jul. 12, 2013.

YONG-ÁNGEL, G. et al. Modeling growth of star grass (Cynodon plectostachyus) in the subtropical regions of central Mexico. Tropical and Subtropical Agroecosystems, v.15, p.273-300, 2012. Available from: <http://www.veterinaria.uady. mx/ojs/index.php/ TSA/article /view/1070>. Accessed: May 30, 2013.

VILELA, D. et al. Desempenho de vacas da raça Holandesa em pastagem de coastcross. Revista Brasileira de Zootecnia, v.35, n.2, p.555-561, 2006. Available from: <http://dx.doi.org/10.1590/ S1516-35982006000200031>. Accessed: Apr. 1, 2013. 